\title{
Characteristics and applications of the water-jet-pump
}

\author{
BY R. SILVESTER

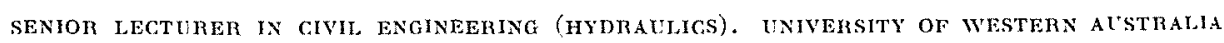

(French text page 461)

\begin{abstract}
The variables in the operation of the water-jetpump are discussed and certain design leatures are outlined. It is stressed that larger units should be more efficient due to the reduction in the frictional component within the throut
\end{abstract} and diffuser. Applications of the rump are
described including the booster system mhere,
in spile of the lomer overall effciencly, the use
of Iower specific speed pamps may hame eco-
nomic and protical admantages.

\section{I. - INTRODUCTION}

The water-jet-pump uses the principle of the ejector pump system in which a fluid at high pressure supplies energy to a fluid at a lower pressure in order to deliver the total flow at some intermediate pressure. This transfer of momentum is accomplished by converting the energy of the driving fluid into velocity form by means of a nozzle and then by turbulent mixing with the driven fluid in a mixing chamber or throat. A diffuser is generally added downstream of the throat to convert most of the resultant velocity energy in the throat into pressure head, but this is not an essential part of the pump.

The variables in the operation of any waterjet-pump are :

$\mathrm{Q}_{m}$ the discharge of the driving fluid;

$\mathrm{Q}_{s}$ the discharge of the driven fluid;

$\mathrm{H}_{m}$ the head upstream of the nozzle;

$\mathrm{H}_{s}$ the suction head-if above atmospheric it is positive;

$\mathrm{H}_{d}$ the delivery head for the total discharge $\left(\mathbf{Q}_{m}+\mathbf{Q}_{8}\right)$.
Head values should include velocity energy al the point of measurement. The above varialleles are closely dependent and are best considered as ratios of differential pressures or discharges.

Although ejector pumps in general and waterjet-pumps in particular have many applications where efficiency is unimportant, the computation of efficiency is useful for designing better pumps and comparing one proportion of pump to another to accomplish the same result. The ratios used to compute efficiency are determined by the mode of use of the pump. There are three main cases to be considered. These are presented diagrammalically in Figure 1, where each unit represents a complete pump in that friction loss in the connecting pipes is ignored.

In (1 a) fluid from an external source is used to pump fluid from one level to another. Efriciency may be computed from the aspect of total output and total input which results in the ratio (I) in table I. This form of the efficiency ratio suffers the defect that its value is affected by elevation of the pump (with respect to the reservoirs). For example, if it were to be very low 

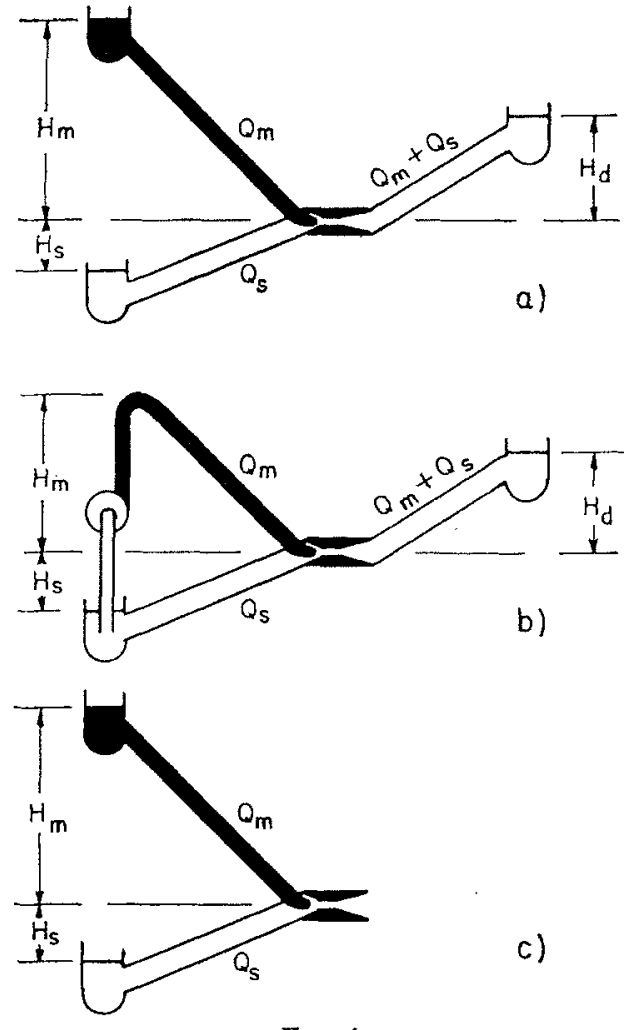

Fra. 1

Diagrammatic form of water-jet-pump.

Friction in the connecting pipes is ignored.

Schéma d'un injecteur hydraulique, établi en négligeant la rugosite des tuyauteries de liaison.

(i.e. $\mathrm{H}_{s}=\mathrm{H}_{d}=\mathrm{H}_{m}$ ) the efficiency tends to unity. Therefore, for conditions of $(1 a)$ it is better to consider work done and energy expended. This results in efficiency ratio (II) in table $I$.

If the driving fluid is drawn from the lower reservoir by means of a pump the useful work consists of both $\mathrm{Q}_{m}$ and $\mathrm{Q}_{s}$ being elevated through a head of $\mathrm{H}_{d}-\mathrm{H}_{s}$. The pump has to supply a head $\mathrm{H}_{m}-\mathrm{H}_{s}$ to $\mathrm{Q}_{m}$, which results in the efficiency ratio (III) in table I.

Figure $1 c$ is a special case of $(1 a)$ where $H_{d}$ is zero, but it is so familiar in air ejectors that it warrants specific mention. The driving discharge is useless except in pumping $Q_{s}$ against the head $\mathrm{H}_{s}$. Depending upon where the jet pump is placed this $\mathrm{H}_{s}$ could be replaced by $\mathbf{H}_{a}$ or by both $\mathrm{H}_{s}$ and $\mathrm{H}_{d}$, but the main factor is that $\mathrm{Q}_{m}$ is not considered as part of the output. Ratio (IV) in table I is applicable to this situation and could serve the case of a hydraulic dredger where the driving water is not required for "diluting" the suspended material.

Several civil engineering applications of waterjet-pumps are listed in Table $I$ with the corresponding efficiency ratios. From the above discussion it is seen that for cases where efficiency may assume some importance ratios (II) and (III) are the most applicable and they will be used in this paper as follows :

$$
\eta=\frac{\mathrm{H}_{d}-\mathrm{H}_{s}}{\mathrm{H}_{m}-\mathrm{H}_{d}} \cdot \frac{\mathrm{Q}_{s}}{\mathbf{Q}_{m}}=\mathrm{N}(\mathrm{M})
$$

and

$$
n^{\prime}=\frac{\mathrm{H}_{d}-\mathrm{H}_{s}}{\mathrm{H}_{m}-\mathrm{H}_{8}} \frac{\mathrm{Q}_{s}+\mathrm{Q}_{m}}{\mathrm{Q}_{m}}=\mathrm{N}^{\prime}(\mathrm{M}+1)
$$

TABLE I

\begin{tabular}{|c|c|c|c|}
\hline & Efficiency Ratio & Applications & Section \\
\hline (J) & $\frac{\mathrm{H}_{d}\left(\mathrm{Q}_{m}+\mathrm{Q}_{s}\right)}{\mathrm{Q}_{m} \mathrm{H}_{m}+\mathrm{Q}_{s} \mathrm{H}_{s}}$ & $\begin{array}{l}\text { Hydraulic dredger } \\
\text { Centrifugal-jet pump }\end{array}$ & $\begin{array}{l}\mathrm{V} 1 \\
\mathrm{~V} 2\end{array}$ \\
\hline (II) & $\frac{\mathrm{H}_{d}-\mathrm{H}_{s}}{\mathrm{H}_{m}-\overline{\mathrm{H}}_{d}} \cdot \frac{\mathrm{Q}_{3}}{\mathrm{Q}_{m}}$ & $\begin{array}{l}\text { Well point system } \\
\text { Tail water suppressor }\end{array}$ & $\begin{array}{l}\text { V } 3 \\
\text { V } 4\end{array}$ \\
\hline (III) & $\frac{H_{d}-H_{s}}{H_{m}-H_{s}} \cdot \frac{Q_{m}+Q_{s}}{Q_{m}}$ & Booster pumping-all types & $\begin{array}{l}\text { V } 6 \\
\text { V } 7\end{array}$ \\
\hline (IV) & $\frac{\mathrm{H}_{s}}{\mathrm{H}_{m}} \cdot \frac{\mathrm{Q}_{s}}{\mathrm{Q}_{m}}$ & Priming devices & V 5 \\
\hline
\end{tabular}

Various ratios for efficiency of the water-jet-pump. 


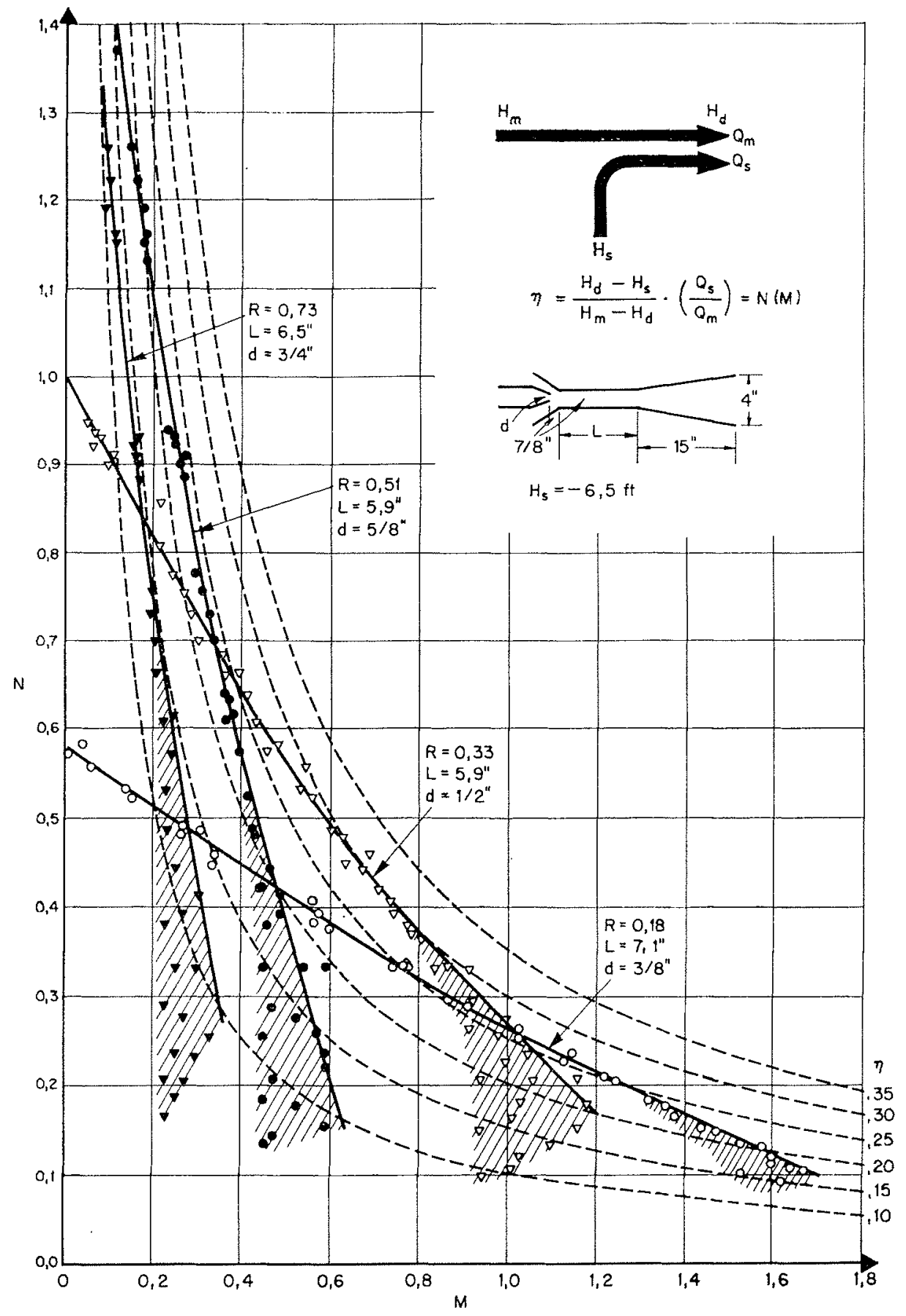

Frg. 2

Characteristic curves based on efficiency ratio (II) in Table $I$.

Courbes caractéristiques établies sur la base du coefficient de rendement (II) du tablean 1 . 


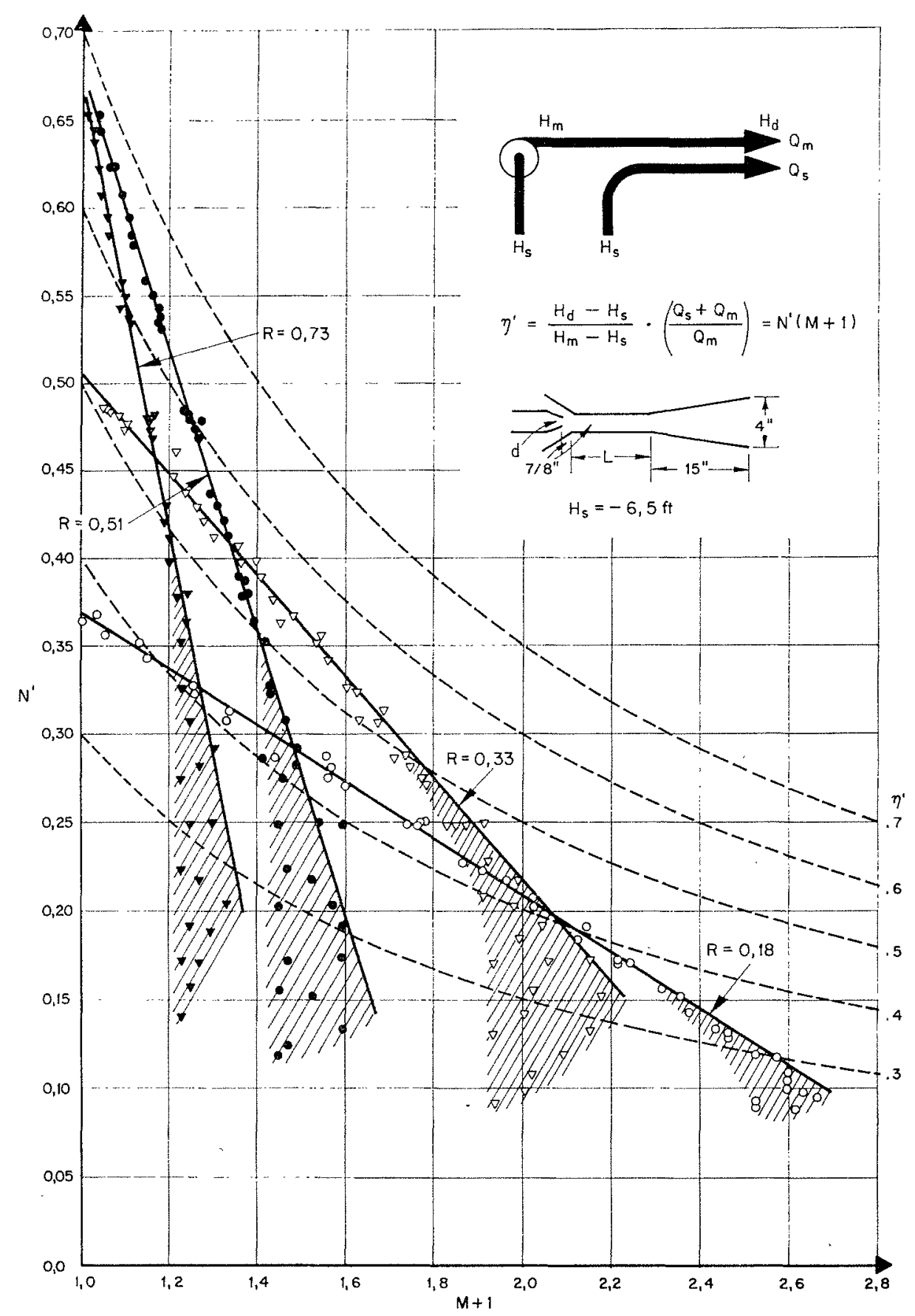

FIG. 3

Characteristic curves based on efficiency ratio (III) in Table I.

Courbes caractéristiques établies sur la base da coefficient de rendement (III) du tableau $I$. 


\section{II. - CHARACTERISTICS}

The general characteristics of the water-jetpump can be expressed as a graph of pressure ratios $N$ or $N^{\prime}$ versus discharge ratios $M$ or $\mathrm{M}+1$ as defined above.

Tests have been conducted at the University of Western Australia on a pump with a throat diameter of $7 / 8^{\prime \prime}$ and four nozzle diameters of $3 / 8^{\prime \prime}$, $1 / 2 " 2^{\prime \prime}, z^{\prime \prime}$ and $34^{\prime \prime \prime}$. The suction head $\left(\mathrm{H}_{s}\right)$ was maintained at $6.5 \mathrm{ft}$. of water below atmospheric, whilst the driving head $\left(H_{m}\right)$ and delivery head $\left(H_{d}\right)$ were varied between the limits 50-120 and 2-60 ft water respectively.

The resultant characteristics, according to the two methods of presentation are illustrated in figures 2 and 3 . The iso-efficiency curves, which can be drawn as soon as the "M-N" scales are chosen, show clearly the preferred regions of operation for any specific proportions of pump.

\section{III. - DESIGN FEATURES}

In designing a water-jet-pump for a particular duty the following main features must be considered :

1. The nozzle to throat area ratio ( $R$ );

2. The throat length (L);

3. The nozzle to throat distance $(x)$;

4. The diffuser length and angle.

The first of these determine the main characteristics of the pump. The remainder affect the efficiency of the momentum transfer to a lesser degree.

\section{Nozzle-Throat Area Ratio (R).}

As seen in Figures 2 and 3 the general slope of the "M-N" curves is dependent upon this ratio and is substantially the same for pumps different in many other respects. The locations of the curves, and hence their ranges of efficiency, are determined by the factors discussed below, especially by the friction encountered in the throat and diffuser.

From considerations of momentum the "M-N" relationship can be obtained theoretically for specific values of the area ration $R$. In Figure 4 can be seen the theoretical solutions by Gosline and O'Brien [1], and by Citrini [2], together with experimental results from two of the tests recorded in Figure 2. Although the values of $R$ vary slightly the slopes of the theoretical curves correspond. well with the experimental results, especially for $\mathrm{R}=0.3$ at the best efficiency point. In general the "M-N" characteristics of actual pumps have a slight curvature upwards denoting a variation of the velocity distribution with changing velocities which apparently reduces the friction factor.

The ratio $R$ also affects performance by limit- ing the entry area for the driven fluid. When the velocity and suction head are increased sufficiently in this annular area the pressure may drop to the water vapour pressure. The resultant cavitation limits the quantity that can be pumped and is illustrated in Figures 2 and 3 by the hatched areas. Although not apparent in

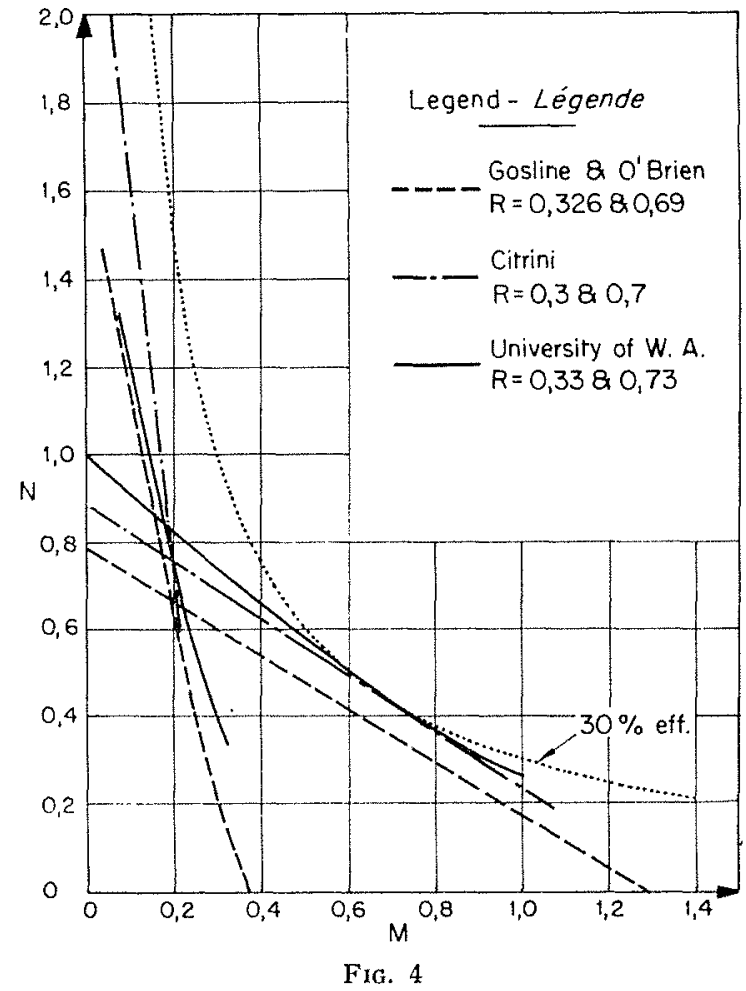

Theoretical solution of the water-jet-pump from Gosline \& O'Brien ("Average friction") and Citrini (Darcy's $f=0.03)$ and experimental results as in Figure 2.

Solution théorique de l'éjectent hydraulique, d'après Gosline et O'Brien ( Rugosité molyenne») et Citrini (coefficient de Darcy $\mathrm{f}=0,03$ ), et résultats expórimentativ suivant la figure 2. 
the figures, the higher the driving head $\left(\mathrm{H}_{m}\right)$ (i.e. the higher the velocity of the driving fluid) the smaller the suction ratio at which cavitation occurs.

The theoretical analysis $[1,2]$ results in an optimum efficiency for $\mathrm{R}=0.3$ based upon the efficiency ratio (II) in table I. Results in figure 2 confirm this since the curve for $\mathrm{R}=0.33$ gives the greatest efficiency of the four ratios tested.

\section{Throat Length (L).}

Kroll [3] has summarised results on air and steam operated ejectors and reports an optimum throat length of 7 times the throat diameter although values from 5-10 gave efficiencies within $3 \%$ of the maximum. Gosline and O'Brien [1] in tests on a water-jet-pump found 6 diameters to be sufficient for complete mixing, any longer throat resulting in frictional loss.

In tests associated with those recorded in Figure 2 and 3 [4] the optimum length was found to vary slightly with the area ratio $R$. It was found that the larger this ratio the shorter the length required; the overall variation was 5-7 diameters. The actual tests recorded in Figure 2 were conducted with the optimum throat lengths previously obtained for all $R$ ratios except 0.73 , for which a complete series of tests was not carried out.

\section{Nozzle-Throat Distances $(x)$.}

Kroll [3] reports that this distance affected the performance greatly in the case of air ejectors and the optimum value varied with the driving head $\left(\mathrm{H}_{m}\right)$, an increase in one required an increase in the other. Gosline and O'Brien found the best distance for the water-jet-pump was one diameter of the nozzle, but other tests [4] have shown it to be one throat diameter.

\section{Diffuser Length and Angle.}

In converting the velocity energy of the combined flow at the downstream end of the throat into pressure the diffuser should not be too long or friction will become excessive, nor should it be too abrupt otherwise eddy losses will increase. For pumps using air [3] the best proportions have been found to be a length of 4-8 times the throat diameter with an included angle of 4-10 degrees which is the usual practice for diffuser design. Very little research has been carried out on this aspect of the waterjet-pump. The ultimate downstream diameter, of course, will be dictated by the delivery velocities desired and the maximum economical length of the pump.

\section{IV. - FRICTION OF INTERNAL SURFACES}

With ejector pumps using air or steam the area ratios $R$ are very small and the boundary friction within the throat can be ignored. In the water-jet-pump this friction assumes importance and, as shown by Citrini [2], produces characteristics substantially different from those computed without it. Citrini supplied characteristic curves for a throat head loss of $0.3\left(\mathrm{~V}^{2} / 2 g\right)$ where $V$ was the mean of the velocities at each end of the throat. Thus, using Darcy's formula $\left[h=f(\mathrm{~L} / d)\left(\mathrm{V}^{2} / 2 g\right)\right]$, for the assumed value of $\mathrm{L} / d=10$, this was equivalent to $f=0.03$. A diffuser efficiency of 0.8 was assumed.

A comparison of the tests recorded in Figure 2 with Citrini's analysis is made in table II where maximum efficiencies (based on (II) in table I) are listed for similar area ratios. These efficiencies correspond closely and show that the friction factor $f=0.03$ was not excessive. This was thought to be the case and curves were included for values of $f=0.02$ and 0.01 . The actual friction factor in the current tests is
0.04 assuming similar diffuser losses and knowing that $\mathrm{L} / d$ averaged 7 .

TABLE II

Comparison of theoretical analyses -according to Citrini--, with results of current tests (Efficiency ratio (II) in Table I).

\begin{tabular}{|c|c|c|}
\hline \multirow{2}{*}{$\mathbf{R}$} & \multicolumn{2}{|c|}{ Maximum Eficienty } \\
\cline { 2 - 3 } & Citrini & Tests \\
\hline 0.18 & 0.29 & 0.28 \\
0.33 & 0.29 & 0.30 \\
0.51 & 0.25 & 0.23 \\
0.73 & 0.15 & 0.15 \\
\hline
\end{tabular}


A similar comparison of the same data, but from Figure 3 (i.e. efficiency ratio (III) in table I), is shown in table III. In this the two values from Citrini refer to pumps $(a)$ with and (b) without diffuser loss. It is seen that the latter fits the test figures slightly better than the former. The reason for this may be a higher diffuser efficiency than the 0.8 assumed by Citrini.

TABLE III

Comparison of theory and practical tests according lo raito (III) in Table $I$.

\begin{tabular}{|c|c|c|c|}
\hline \multirow{2}{*}{$\mathrm{R}$} & \multicolumn{3}{|c|}{ Maximum Efficienty } \\
\cline { 2 - 4 } & \multicolumn{2}{|c|}{ Citrini } & Tests \\
\hline & $(a)$ & $(b)$ & \\
0.18 & 0.30 & 0.44 & 0.42 \\
0.33 & 0.50 & 0.55 & 0.55 \\
0.51 & 0.64 & 0.67 & 0.68 \\
0.73 & 0.68 & 0.70 & 0.65 \\
\hline
\end{tabular}

The friction factor $f=0.04$ computed above for the current tests was obtained for a pump consisting of finely machined bronze parts which screwed tightly together. This value therefore appears high, corresponding as it does to $k / d=0.012\left(^{\star}\right)$ which for $d=z / s^{\prime \prime}$ is equivalent to cast iron roughness. This must be due to the excessive turbulence and the high peripheral velocities for the discharge involved.

On an average these tests would have been conducted at a throat Reynolds number of $2 \times 10^{5}$ (i.e. a mean throat velocily of $30 \mathrm{ft} . / \mathrm{sec}$.). On the Moody diagram of $f$ versus Reynolds number, this occurs near the fully turbulent region, in which case $f$ is determined mainly by $k / d$. Thus for the same material a larger but geometrically similar pump must have a lower friction factor. Observation of the Moody diagram shows that a four-fold increase in diameter reduces $f$ to 0.03 , whilst for a pump 15 times larger $f$ would be 0.02 . These values are equivalent to throat diameters of 3.5 and 13 inches respectively with a machined metal finish. It is extremely unlikely that a value of $f=0.01$ could be obtained. The increase in maximum efficiency given by Citrini for a drop in friction factor from 0.03 to 0.02 is appproximately $5 \%$.

\section{V. - APPLICATIONS}

There are many applications of the water-jetpump where its efficiency is of secondary importance compared with its versatility and stability of operation. For example, where air may be present in a suction line or where erosive and corrosive mixtures have to be pumped it has special advantages. But even where efficiency is an economic criterion in the choice of a pumping system the jet pump may be able to compete freely with the normal centrifugal system. The main civil engineering applications are as follows :

\section{Dredging.}

Recently the water-jet-pump has been embodied in a hydraulic dredger [5], which was combined with jets for throwing bed material into suspension. Although the efficiency is not high (ratio II, table I) compared to a direct largecapacity unit the advantages are that (I) sediment laden water does not travel through the pump (II) the line which would normally be under suction is now pressurised.
A diagrammatic sketch of such a system is given in figure $5 a$.

\section{High Lift Pumping.}

The centrifugal-jet-pump combination is well known in the domestic field [6] where efficiencies are not as important as the advantage of siting the centrifugal unit above ground (see figure $5 \mathrm{~b}$ ). Portion of the centrifugal output is used to boost the suction pressures in order to prevent cavitation.

\section{Well-point Systems.}

By using a high pressure supply a number of well-points (with-jet-pump altached) can discharge ground water against substantial pressures [7] (see figure $5 \mathrm{c}$ ). The advantages of this system over the usual suction layout arc:

(*) $k$ is the roughness dimension. 


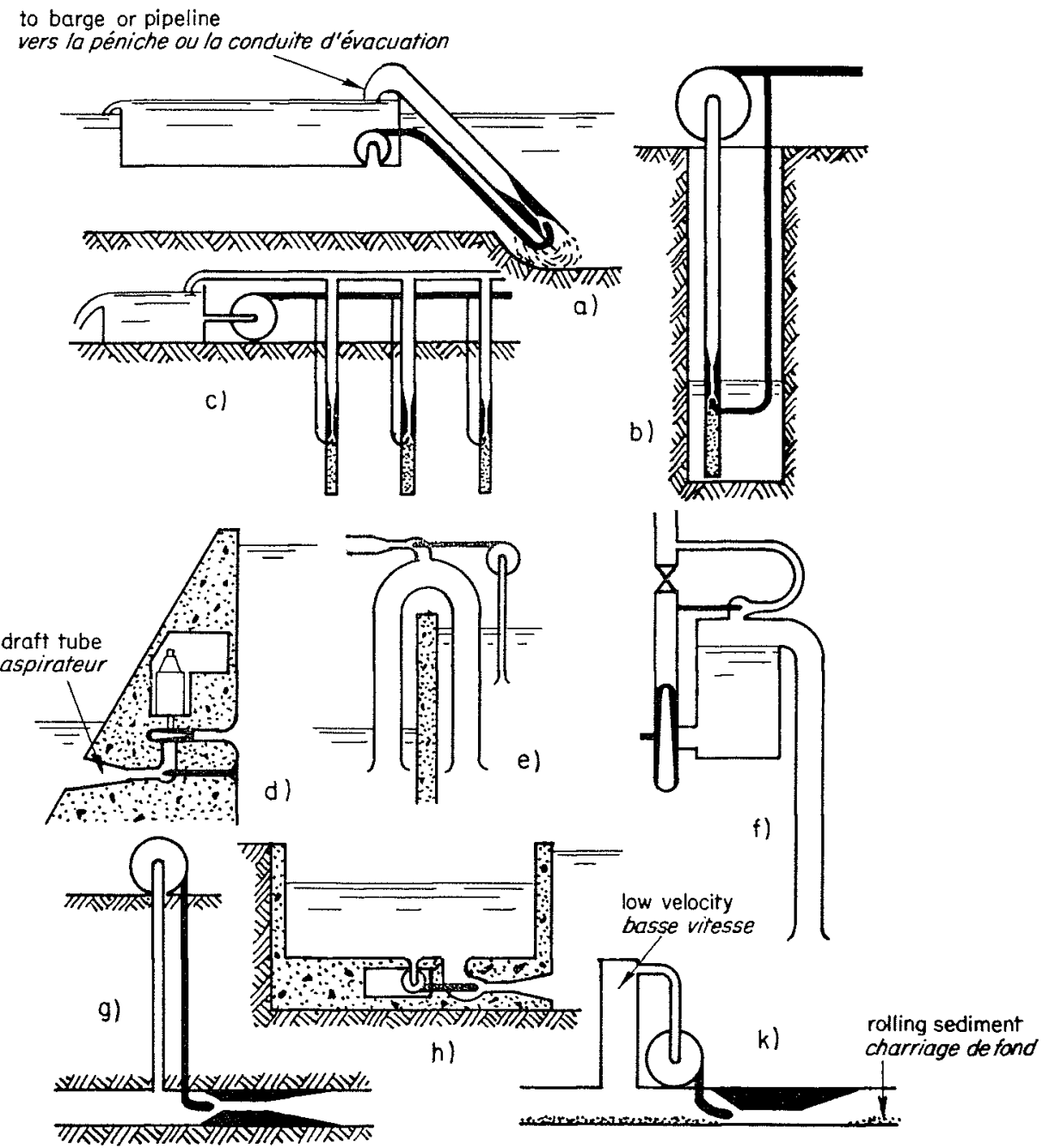

FIG. 5

Applications

of the water jet-pump in civil engineering.

Utilisations

des éjecteurs hydrauliques en génil civil.
a) Hydraulic dredger;
b) Suction head booster;
c) Well-point system;
d) Tail water suppressor;
e) Siphon primer;
f) Pump primer;
g) Pipe line booster;
h) Dry dock eductor;
k) Sediment transportation.
a) Drague hydraulique;
b) Augmentation de la hauteur d'aspiration;
c) Pompage en puits;
d) Réduction des pressions dans les canaux de faite;
e) Amorcage des siphons;
f) Amorçage des pompes;
§) Pompage d'appoint pour les conduites:
h) Exhaure des bassins de radoub;
k) Transport des matériaux solides.

a) The whole pipe system is under pressure, making leaks clearly visible;

b) The lift of a single stage can be much greater than the normal 20 feet;

c) Should air be drawn into the well point, say by an unforeseen drop in the water table, it is educted without the system becoming deprimed.

\section{Tail water suppressors.}

The possibility of using jet-pumps during flood periods to reduce tail water pressures has been discussed in detail elsewhere [8]. There appear to be applications for Pelton, Francis and Kaplan turbine installations. A typical case is shown in figure $(5 d)$.

\section{Priming devices.}

Siphons can be actuated swiftly by means of water-jet-pumps if water under pressure is available (figure $5 e$ ). By continuous operation such a pump can also obviate the accumulation of vapour from aeration or air leaks under negative head conditions.

A simple self-priming device for a centrifugal pump is shown in figure $(5 f)$. It consists of a small tank on the suction side of the pump with a water-jet-pump attached to the top across the discharge valve. On starting, the discharge valve is closed and the reservoir is used to feed the ejector which withdraws the air from the suction line. When the whole suction passage is filled with liquid the discharge valve can be opened. No foot valve is required on such an installation, which would compensate for the extra head loss due to the reservoir.

\section{Booster pumping.}

In figure $(5 g)$ is shown diagrammatically a booster unit on a pressure main, which utilises the water-jet-pump. The advantages of this 
arrangement over the normal large capacity, low head pump it could replace are:

a) A lower specific speed pump can be used which could well be a stock machine and not a special unit;

b) The pump can be replaced more easily as higher heads are required, or a second machine placed in series with it;

c) The difficulties due to the rising power curve of the high specific speed unit are avoided;

d) The instability caused by the flatness of the head characteristic of the same unit need not be suffered;

e) If the pipe-line is deep in the ground the driving pump can be set above ground with the minimum of pressure loss;

f) The throat and nozzle can be built into the main at the outset because they will offer little resistance when not being used as a booster;

g) The requisite control valves are smaller;

h) The water hammer effect on stopping and starting is decreased.

As can be seen in figure 3 , the efficiency for the jet section of a booster pump can be of the order of $50 \%$. The economics of a sysem can best be illustrated by an example.

\section{Example :}

It is required to boost a flow of 7 cusecs in a main by 30 feet. What are the specific speeds of the pumps required with and without the assistance of the water-jet-pump? Determine also the size of the motors. The speed of rotation in each case will be taken as 1650 R.P.M.
For a single pump the specific speed $n_{s}=7080$ (U.S. gpm, ft, units). Using the efficiency of 0.81 given by Stepanoff [6], p. 85, the motor required is 30 H.P.

A water-jet-pump with throat ratio 0.33 (see figure 3) gives certain values of $\left(Q_{s}+Q_{m}\right) /\left(Q_{m}\right)$ (i.e. $M+1$ ) for specific values of

(i.e. $\mathrm{N}^{\prime}$ ).

$$
\left(\mathrm{H}_{d}-\mathrm{H}_{s}\right) /\left(\mathrm{H}_{m}--\mathrm{H}_{s}\right)
$$

The head $\left(\mathrm{H}_{m}-\mathrm{H}_{z}\right)$ and discharge $\left(\mathrm{Q}_{m}\right)$ of the pump can thus be obtained and hence $n_{x}$. Using the efficiencies of Stepanofff as above, the required H.P. motor can be determined,

Values are listed in table IV.

It is seen that the jet unit requires a larger motor the cost of which must be balanced against any saving in the cost of the pump, valves, stand-by units and the other advantages listed above. Slightly better efficiencies could be expected than those in figure 3 with the larger proportions of the jet pump, that is the "M-N" curves could be displaced to the right.

This booster system may have applications in dry-docks where the variation in head on the pumps is obviated. Also the pumping head available can be used for other services, especially if divided among units that can be placed in series or parallel. A typical installation is presented diagrammatically in figure $5 \mathrm{~h}$.

In sewage pumping stations it may be possible to keep part of the effluent free from solids which could then be passed through a normal centrifugal pump to drive a water-jet-unit so proportioned as to take the solid material. Such a system could have an overall efficiency in excess of that obtainable with the wide passage sludge pumps.

The water jel should certainly find applica-

TABLE IV

Design computation for a water-jel-pump booster system.

\begin{tabular}{|c|c|c|c|c|c|c|}
\hline $\mathrm{N}^{\prime}$ & $M+1$ & $\mathrm{H}_{m}-\mathrm{H}_{s}$ & $Q_{m}$ & $n_{\text {. }}$ & $\begin{array}{c}\text { Efficiency } \\
\%\end{array}$ & H.P. \\
\hline 0.16 & 2,2 & 188 & 3.2 & 1220 & 83.0 & 82 \\
\hline 0.22 & 2,0 & 137 & 3.5 & 1610 & 85.5 & 64 \\
\hline 0.275 & 1.8 & 109 & 3.9 & 2030 & 86.5 & 56 \\
\hline 0.33 & 1.6 & 91 & 4.4 & 2480 & 87.0 & 52 \\
\hline 0.39 & 1.4 & 77 & 5.0 & 3000 & 86.0 & 51 \\
\hline 0.45 & 1,2 & 67 & 5.8 & 3600 & 85.5 & 52 \\
\hline
\end{tabular}


tion in temporary drainage problems involving low heads and large quantities when portable pump units of reasonably high heads only are stocked for construction work.

\section{Pumping Sediment.}

The pumping of materials in suspension is increasing in importance as other transport costs rise. The advantage of the jet-pump booster system here is obvious if means are provided to prevent erosive material from entering the centrifugal unit. An installation is sketched in figure $5 k$ where the pump passes only the finest sediment because the water velocity up the riser is below the settling velocity of the coarser material.

Other advantages of this scheme are:

a) The pump can be located at a convenient point with respect to the line;

b) In the case of a shut-down the impeller is not blocked with sediment;

c) If the venturi section has a constant invert level as shown, the sediment will not build up and restrict passages in the pipe-line.

\section{VI. - CONCLUSIONS}

This discussion and the tests reported herein lead to the following conclusions:

a) Efficiency computations of the water-jetpump vary with the uses made of it; some civil engineering applications can include values of $50-60 \%$.

b) The characteristics of this pump are clearly defined by the "M-N" diagrams (which include iso-efficiency curves) except when cavitation occurs. Although further research is required on some design aspects of the jet puinp sufficient is known for its wider application;

c) Frictional resistance in larger scale pump is less than for geometrically smaller units and should result in higher efficiencies;

d) The water-jet-pump has already been applied in many and varied pumping problems, due no doubt to its stability and ver'satility, but further utilisation seems possible.

\section{REFERENCES}

[1] J.E. Gosline \& M.P. O'Brien. - The Water Jet Pump, University of California, Pub. in Eng., Vol. 3, No. 3, 1934, p. 167.

[2] D. Catrini. - Contribution à l'étude des éjecteurs, ou trompes hydrauliques, La Houille Blanche, Vol. $11, \mathrm{n}^{\circ} 6$, déc. 1956, p. 837.

[3] A. E. Kroll. - The Design of Jet Pumps. Chemical Eng. Prog., Vol. 1, 1947, p. 21.

[4] A.G. Beales \& R.M. Peiry. -- Jet Pump Characteiistics. Bachelor of Eng. Thesis, University of W.A,. 1953 (unpublished).
[5] Anon. - Hydraulic Dredger, The Engineer, Vol. 206, 1958 , p. 818.

[6] A. J. Stepanoff. - Centrifugal and Axial Flow Pumps, John Wiley \& Sons, 1948, 1st ed.

[7] Anon. - Water Removed Water from Deep Cutand-Cover Tunnel. Eng. News. Rec., Oct. 1, 1959, p. 34.

[8] R. Srvester. - Water Jet Pump - Its use in HydroElectric Schemes, Water Power, Vol. 12, 1960, p. 176 . 


\title{
Caractéristiques et utilisations des éjecteurs hydrauliques
}

\author{
PAR R. SILVESTER \\ SENIOH LECTUHER IN GIVIL ENGINEERINA (HYDRAULICS). UNIVERSTTY OF WESTERN AUSTRALIA
}

(Voir les illustrations au texte anglais, page 451)

\begin{abstract}
L'auteur examine les variables intervenant dans le fonctionnement des cjectcurs hydrauliques, et décrit grosso modo certaines caractéristiques de leur conception. Il souligne que les ejecteurs de grande taille doivent, en principe, anoir un meilleur rendement, étant donné qu'ils présentent une composante de frottemont
\end{abstract}

\begin{abstract}
réduite dans l'étranglement et dans le diffuseur. Il décrit un certain nombre d'utilisations d'appoint, dans lesquelles les pompes à vitesse spécifique moins élevée peuvent présenter des avantages d'ordre économique et pratique, malgré leur rendement global moins élevé.
\end{abstract}

\section{I. - INTRODUCTION}

L'éjecteur hydraulique fonctionne suivant le principe d'un éjecteur classique, dans lequel un fluide à haute pression fournit de l'énergie à un fluide dont la pression est moins élevée, afin d'assurer un débit global à une pression intermédiaire quelconque. Ce transfert de quantité de mouvement s'accomplit grâce à la conversion de l'énergie du fluide moteur en vitesse au moyen d'une tuyère, puis grâce au mélange turbulent des fluides moteur et entraîné, à l'intérieur d'une chambre de mélange ou d'un étranglement. On prévoit généralement un diffuseur à l'aval de l'étranglement, afin de transformer en pression la plus grande partie de l'énergie de vitesse établie dans l'étranglement; un tel dispositif ne constitue cependant pas une partie essentielle de l'éjecteur. Les variables intervenant dans le fonctionnement de tout éjecteur hydraulique sont :

$Q_{m}$ le débit du fluide moteur;

$Q_{s}$ le débit du fluide entraîné;

$\mathrm{H}_{n}$ la hauteur à l'amont de la tuyère;

$\mathrm{H}_{s}$ la hauteur d'aspiration (celle-ci étant positive, lorsqu'elle est supérieure à la pression atmosphérique);

$H_{d}$ la hauteur totale de refoulement, pour le débit; total $\left(Q_{n}+Q_{s}\right)$.
Les valeurs des hauteurs doivent, en principe, tenir compte de l'énergie de vitesse au point de mesure. Les variables énumérées ci-dessus sont toutes en relation étroite entre elles, de sorte que l'on les considérera, en premier lieu, comme étant des rapports de pressions différentielles ou de débits.

Bien que les éjecteurs en général, et surtout les éjecteurs hydrauliques, puissent être utilisés dans bien des cas où le rendement est d'une importance mineure, le calcul du rendement est néanmoins utile lorsqu'il s'agit de mettre au point des éjecteurs améliorés, et pour la comparaison de diverses tailles d'éjecteurs permettant d'obtenir un rendement donné. Le choix des rapports utilisés pour calculer le rendement dépend du mode d'utilisation de l'éjecteur en question. Trois cas fondamentaux se présentent, étant représentés schématiquement par la figure 1 , dans laquelle chaque schéma représente un éjecteur complet, à condition toutefois de négliger les pertes dues au frottement dans les tuyauteries de liaison.

Dans la figure $1 a$, un fluide provenant d'une source extérieure sert à pomper un autre fluide à partir d'un certain niveau, et jusqu'à un deu. xième niveau plus élevé. 
La considération des puissances totales à l'entrée el à la sortie permet de calculer le rendement, ce qui donne le coefficient (I) du tableau I. Cependant, exprimé sous cette forme, le coefficient de rendement présente un défaut, c'est-à-dire que sa valeur dépend de la hauteur de calage de la pompe par rapport aux réservoirs. Par exemple, le rendement tend vers l'unité lorsque la pompe se trouve calée très bas (c'est-à-dire que $\mathrm{H}_{s}=\mathrm{H}_{d}=\mathrm{H}_{m}$ ). Il est donc préférable, dans le cas ( $1 a)$, de tenir compte du travail effectué et de la dépense d'énergie, ce qui permet d'obtenir le coefficient de rendement (II) du tableau $\mathbf{I}$.

Lorsque le fluide d'entraînement est aspiré à partir du réservoir inférieur par une pompe, le travail utile consiste en l'èlévation, à la fois, de $\mathrm{Q}_{m}$, et de $\mathbf{Q}_{s}$, sur une hauteur $\mathbf{H}_{d}-\mathbf{H}_{s}$. La pompe doit fournir une hauteur $\mathrm{H}_{m}-\mathrm{H}_{s}$ à $\mathrm{Q}_{m}$, ce qui donne le coefficient de rendement (III) du lableau I.

La figure $1 c$ représente un cas particulier de (1 $a$ ), pour $H_{d}=0$; cependant, ce cas présente assez fréquemment pour les éjecteurs à air, de sorte qu'il mérite une mention particulière. Le débit d'entraînement est sans aucune utilité, sauf s'il refoule $\mathbf{Q}_{s}$ contre la hauteur $\mathbf{H}_{s}$. Suivant la position de l'éjecteur, on pourrait remplacer ce $\mathrm{H}_{s}$, soit par $\dot{\mathrm{H}}_{d}$, soit à la fois par $\mathrm{H}_{s}$ et $\mathrm{H}_{d}$; toutefois, le point essentiel à retenir esl que $\mathrm{Q}_{m}$ n'est pas considéré comme étant compris dans la puissance de sortie. Le coefficient (IV) du tableau I s'applique à cette situation, et pourrait convenir au cas d'une drague hydraulique, pour laquelle l'eau d'entraînement n'est pas requise pour «diluer» les matériaux en suspension.

Le tableau I présente plusieurs utilisations des éjecteurs hydrauliques en génie civil, ainsi que les coefficients de rendement correspondants. On voit d'après ce qui précède que, dans les cas où le rendement est susceptible de revêtir une certaine importance, ce sont les coefficients (II) et (III) qui conviennent le mieux. Ces coefficients seront utilisés dans le présent rapport de la manière suivante :

et

$$
\eta=\frac{\mathrm{H}_{d}-\mathrm{H}_{s}}{\mathrm{H}_{m}-\mathrm{H}_{d}} \cdot \frac{\mathrm{Q}_{*}}{\mathrm{Q}_{m}}=\mathrm{N}(\mathrm{M}),
$$

$$
\eta^{\prime}=\frac{\mathrm{H}_{a}-\mathrm{H}_{s}}{\mathrm{H}_{m}-\mathrm{H}_{s}} \frac{\mathrm{Q}_{s}+\mathrm{Q}_{m}}{\mathrm{Q}_{m}}=\mathrm{N}^{\prime}(\mathrm{M}+1)
$$

TABLEAU I

Divers coefficients de rendement des éjecteurs hydralliques.

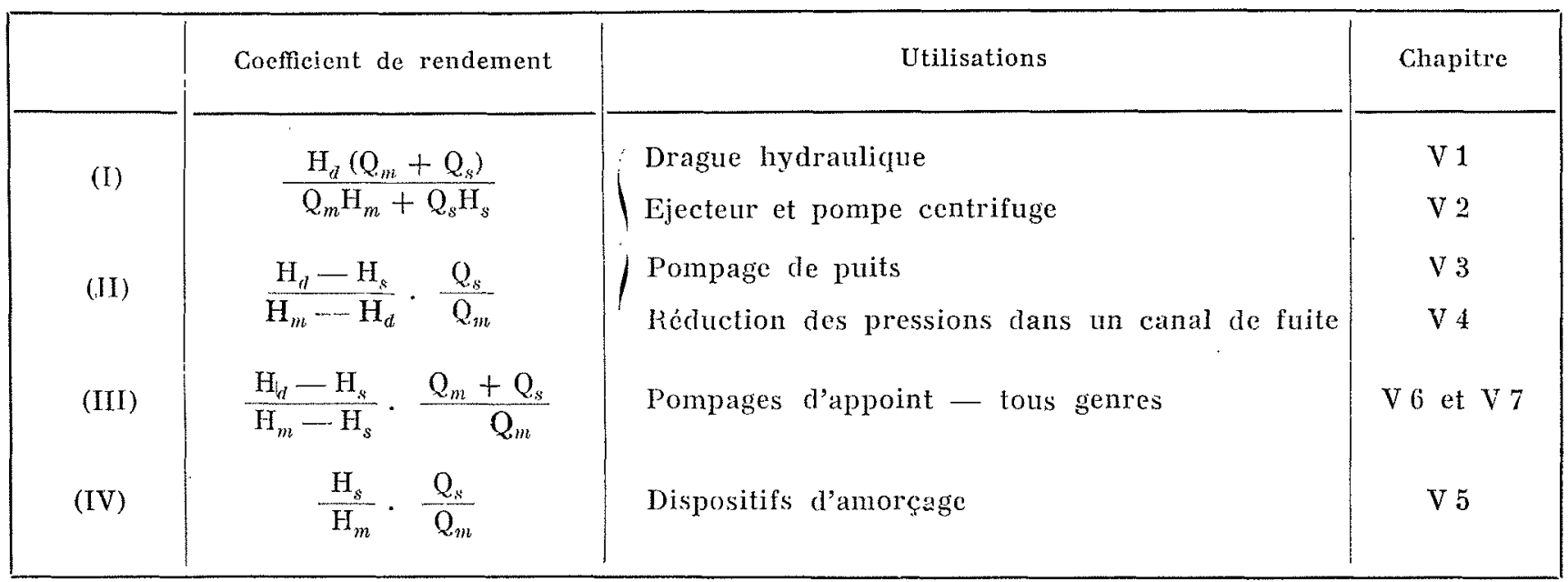

\section{II. - CARACTERISTIQUES}

Les caractéristiques générales de l'éjecteur hydraulique peuvent être représentées par une courbe exprimant les rapports de pression, $\mathbf{N}$ ou $\mathrm{N}^{\prime}$, en fonction des rapports de débit, $\mathrm{M}$ ou $\mathrm{M}+1$, définis dans ce qui précède.

Des essais ont élé effectués à l'Université
d'Australie occidentale, avec une pompe comportant un étranglement de $7 / 8^{\mathrm{e}}(22,2 \mathrm{~mm})$ pouce, et avec des tuyères de $3 / 8^{\mathrm{e}}(9,5 \mathrm{~mm})$ pouce, $1 / 2(12,7 \mathrm{~mm})$ pouce, $5 / 8^{\mathrm{e}}(15,8 \mathrm{~mm})$ pouce, et $3 / 4(19 \mathrm{~mm})$ pouce de diamètre. La hauteur d'aspiration $\left(\mathrm{H}_{s}\right)$ a été maintenue à la 
valeur de $6,5(1,97 \mathrm{~m})$ pieds au-dessous de la pression atmosphérique, tout en faisant varier la hauteur motrice $\left(\mathbf{H}_{m}\right)$ entre les limites de 50 $(15 \mathrm{~m})$ et $120(36 \mathrm{~m})$ pieds d'eau, et la hauteur de refoulement entre les limites de $2(0,60 \mathrm{~m})$ à $60(18 \mathrm{~m})$ pieds d'eau.

Les caractéristiques obtenues suivant ces deux méthodes de présentation sont représentées sur les figures 2 et 3 . Les courbes d'égal rendement, qui peuvent être tracées dès que l'on a choisi les échelles « $\mathrm{M} »$ et $《 N \gg$, montrent nettement les zones de fonctionnement préférentielles, en fonction des dimensions spécifiques de la pompe.

\section{III. - DONNEES DE CALCUL}

L'étude d'un éjecteur hydraulique, pour une utilisation donnée, doit tenir compte des données essentielles suivantes :

1. Rapport de la section de la tuyère à celle de l'étranglement $(R)$;

2. Longueur de l'étranglement (L);

3. Distance de la tuyère à l'étranglement $(x)$;

4. Longueur et angle du diffuseur.

La première de ces données détermine les caractéristiques principales de la pompe; l'influence des autres données sur le rendement de l'échange de quantité de mouvement est moins importante.

\section{Rapport entre les sections de la tuyère et de l'étranglement (R).}

L'examen des figures 2 et 3 montre que la pente générale des courbes $《 \mathbf{M}-\mathbf{N}$ 》 dépend de ce rapport, et qu'elle reste pratiquement la même pour des pompes dissemblables à d'autres points de vue. Les situations de ces courbes, et donc des gammes de rendement qu'elles représentent, sont déterminées par les facteurs que nous examinerons par la suite, dont surtout le frottement à l'intérieur de l'étranglement et du diffuseur.

L'examen des quantités de mouvement en jeu permet d'obtenir la relation $《 M-N 》$ théoriquement, pour des valeurs bien déterminées du rapport des sections $R$. La figure 4 représente les solutions théoriques obtenues par Gosline et O'Brien [1] et par Citrini [2], ainsi que les résultats de deux des essais représentés sur la figure 2 . Bien que les valeurs de $R$ varient légèrement, les pentes des courbes théoriques s'accordent bien avec les résultats expérimentaux, surtout pour $R=0,3$, au point de rendement optimal. En général, les caractéristiques « $\mathrm{M}-\mathrm{N}$ 》 des pompes réelles comportent une légère courbure vers le haut; ceci indique que la répartition des vitesses varie en même temps que les vitesses elles-mêmes, ce qui parait avoir pour effet de réduire le coefficient de frottement.

Le rapport $R$ influe également sur le fonctionnement, en limitant la section d'entrée du fluide entraîné. Lorsque la vitesse et la hauteur d'aspiration augmentent suffisamment à l'intérieur de cet espace annulaire, il peut arriver que la pression diminue jusqu'à atteindre la pression de vapeur de l'eau. La cavitation ainsi provoquée limite la quantité qu'il est possible de pomper, ce qui est représenté par les zones hachurées des figures 2 et 3 . Bien que ces figures ne le montrent pas, plus la hauteur motrice $\mathrm{H}_{m}$ (c'est-à-dire la vitesse du fluide d'entraînement) est importante, plus la valeur du rapport de dépression, à laquelle se produit la cavitation, diminue.

L'analyse théorique $[1,2]$ donne un rendement optimal pour $\mathrm{R}=0,3$, sur la base du coefficient de rendement (II) du tableau $I$. Ce résultat se trouve confirmé par ceux de la figure 2 , étant donné que le rendement le plus élevé, pour les quatre coefficients essayés se situe sur la courbe correspondant à $\mathrm{R}=0,33$.

\section{Longueur de l'étranglement (L).}

Kroll [3] a résumé les résultats obtenus avec des éjecteurs fonctionnant à l'air et à la vapeur. D'après ces résultats, la Iongueur d'étranglement optimale serait égale à 7 fois le diamètro de l'étranglement, bien que des longueurs de 5 à 10 fois ce diamètre aient également donné des rendements différant de $3 \%$ de la valcur maximale. Gosline et O'Brien [1] ont fait des essais avec un éjecteur hydraulique, et ils ont trouvé qu'une longueur égale à 6 fois le diamctre de l'étranglement suffisait pour assurer un mélange complet; en outre, toute valeur dépassant celte limite provoquait des pertes, dues au frottement.

Les auteurs du présent mémoire ont pu observer pendant des essais complémentaires à ceux représentés par les figures 2 et 3 [4], que la longueur optimale variait légèrement en fonc- 
tion $\mathrm{du}$ rapport des sections $\mathrm{R}$. II est apparu que, plus ce rapport était élevé, plus la longueur nécessaire se trouvait réduite; la variation globale était de 5 à 7 diamètres. Les essais représentés sur la figure 2 ont été effectués avec les longueurs d'étranglement optimales obtenues antérieurement pour tous les rapports $R$, à l'exception de 0,73 , valeur pour laquelle il n'a été fait aucune série complète d'essais.

\section{Distance entre la tuyère et l'étrangle- ment $(x)$.}

D'après Kroll [3], cette distance influerait fortement sur le fonctionnement des éjecteurs à air, et la valeur optimale varierait en fonetion de la hauteur motrice $\left(H_{m}\right)$, c'est-à-dire que toute augmentation de l'une de ces variables entrainerait une augmentation de l'autre. Gosline et O'Brien ont trouvé que, pour un éjecteur hydraulique, la distance optimale correspondrait à une fois le diamètre de la tuyère, mais d'autres essais [4] ont montré qu'elle correspond, en fait, à une fois le diamètre de l'étranglement.

\section{Longueur et angle du diffuseur.}

Pour la transformation de l'énergie de vitesse de l'écoulement combiné, à l'extrémité aval de l'étranglement, en énergie de pression, le diffuseur ne doit pas ètre trop long, sinon il risque de provoquer un frottement excessif. De mème, un angle de diffuseur trop raide augmenterait les pertes turbulentes. Il a été reconnu que les dimensions optimales des éjecteurs fonctionnant à l'air [3] étaient les suivantes : longueur $=4$ à 8 fois le diamètre de l'étranglement, le diffuseur enfermant un angle total de 4 à $10^{\circ}$, ce qui correspond aux dimensions des diffuseurs classiques. Cet aspect de l'éjecteur a été très peu étudié jusqu’à maintenant. Bien entendu, le diamètre aval définitif dépendra, dans chaque cas, des vitesses envisagées à la sortie, ainsi que de la longueur économique maximale de l'éjecteur.

\section{IV. - FROTTEMENT DES SURFACES INTERIEURES}

Pour les éjecteurs fonctionnant à l'air ou à la vapeur, les rapports de section $R$ sont très faibles, et l'on peut négliger le frottement à la couche limite à l'intérieur de l'étranglement. Par contre, pour les éjecteurs hydrauliques, ce frottement devient important, et, ainsi que le démontre Citrini [2], il donne lieu à des caractéristiques très différentes de celles calculées en le négligeant. Citrini a établi des courbes caractéristiques pour une perte de charge, à l'étranglement, de $0,3 \mathrm{~V}^{2} / 2 g$, dans laquelle $\mathrm{V}$ représentait la moyenne des vitesses aux deux extrémités de l'étranglement. Ainsi, en utilisant la formule de Darey

$$
\left[h=f(\mathrm{~L} / d)\left(\mathrm{V}^{2} / 2 g\right)\right]
$$

et en admettant $L / d=10$, ceci correspondait à $f=0,03$. Il a été admis un rendement de 0,8 pour le diffuseur.

Le tableau II confronte les essais de la figure 2 avec l'analyse de Citrini, les rendements maximaux (basés sur (II) du tableau I) étant indiqués pour des rapports de section analogues dans les deux cas. La correspondance étroite entre ces rendements démontre que la valeur $f=0,03 \mathrm{du}$ coefficient de frottement n'était pas excessive.
Ainsi, notre supposition s'est trouvée confirmée, et nous avons tracé des courbes correspondant à $f=0,02$ et $f=0,01$. Le coefficient de frottement réel des essais courants est de 0,04 , en admettant des pertes analogues au diffuseur, et sachant que la valeur moyenne de $\mathrm{L} / d$ était égale à 7 .

\section{TableaU II}

Confrontation des analyses théoriques (d'après Citrini) et des résultats des essais courants (coefficient de rendement (II) dn tableau I).

\begin{tabular}{|c|c|c|}
\hline $\mathrm{R}$ & \multicolumn{2}{|c|}{ Rendement maximum } \\
\hline & Citrini & Essais \\
\hline 0,18 & 0,29 & 0,28 \\
0,33 & 0,29 & 0,30 \\
0,51 & 0,25 & 0,23 \\
0,73 & 0,15 & 0,15 \\
\hline
\end{tabular}


Une comparaison analogue des mêmes données, mais basées, cette fois, sur la figure 3 (c'est-à-dire sur le coefficient de rendement (III) du tableau I) est présentée dans le tableau III. Dans ce tableau, les deux valeurs fournies par Citrini correspondent à des pompes ( $a$ ) avec et (b) sans pertes au diffuseur; les valeurs de ces dernières s'accordent un peu mieux avec les résultats d'essai que celles des premières. La raison en est, peut-être que le rendement du diffuseur était supérieur à la valeur de 0,8 admise par Citrini.

\section{TABLEAU III}

Confrontation de la théorie et des résultats expérimentaux suivant le coefficient (III) da tablean I).

\begin{tabular}{|c|c|c|c|}
\hline \multirow{2}{*}{$\mathrm{R}$} & \multicolumn{3}{|c|}{ Rendement maximum } \\
\cline { 2 - 4 } & \multicolumn{2}{|c|}{ Citrini } & Essais \\
\hline & $(a)$ & $(b)$ & \\
0,18 & 0,30 & 0,44 & 0,42 \\
0,33 & 0,50 & 0,55 & 0,55 \\
0,51 & 0,64 & 0,67 & 0,68 \\
0,73 & 0,68 & 0,70 & 0,65 \\
\hline
\end{tabular}

Le coefficient de frottement $f=0,04$, calculé comme indiqué ci-dessus pour les essais courants, a été obtenu pour un éjecteur composé d'éléments en bronze usinés avec précision el vissés de manic̀re à constituer un ensemble bien ajusté. Cette valeur paraît donc être plutôt élevée, étant donné qu'elle correspond à

$$
k / d=0,012\left(^{\star}\right)
$$

ce qui, pour $d=7 / 8^{\mathrm{e}}$ de pouce, $(22,2 \mathrm{~mm})$, correspond à la rugosité de la fonte. Ceci est probablement dû, à la fois, à la turbulence excessive, et aux vitesses périphériques élevées, par rapport au débit en question.

Dans la moyenne, ces essais auraient été effectués pour un nombre de Reynolds, à l'étranglement, de $2 \times 10^{5}$ (c'est-à-dire à une vitesse moyenne de $30 \mathrm{ft} . / \mathrm{sec} .(9,14 \mathrm{~m} / \mathrm{s})$. Sur l'abaque de Moody exprimant $f$ en fonction du nombre de Reynolds, cette condition se produit au roisinage de la région entièrement turbulente, dans lequel cas $f$ est déterminé principalement par $k / d$. Ainsi, pour un matériau donné, une pompe plus grande doit, à condition de respecter la similitude géométrique, comporter un coefficient de frottement moins élevé. L'examen de l'abaque de Moody montre que, pour un diamètre 4 fois plus grand, la valeur de f se réduit à 0,03 , alors que, pour une pompe 15 fois plus grande, $f$ serait de 0,02 . Ces valeurs correspondent, respectivement, à des diamètres d'étranglement de 3,5 pouces $(88,9 \mathrm{~mm})$ et de 13 pouces $(330 \mathrm{~mm})$, pour une surface métallique usinée. Il est très peu probable que l'on puisse obtenir pour $f$ une valeur de 0,01 . L'augmentation du rendement maximal indiqué par Citrini, pour une diminution du coefficient de frottement de 0,03 à 0,02 , est de l'ordre de $5 \%$.

\section{V. - UTILISATIONS}

Il existe plusieurs utilisations possibles des éjecteurs hydrauliques, dans lesquelles le rendement est d'une importance secondaire, par rapport à l'adaptabilité et à la stabilité de fonctionnement de ces dispositifs. Par exemple, les éjecteurs hydrauliques présentent des avantages tout particuliers dans les cas où l'on doit envisager la présence d'air à l'intérieur de la tuyauterie d'aspiration, ou bien lorsqu'il s'agit de pomper des mélanges érosifs ou corrosifs. Cependant, même dans les câs où le rendement est un critère économique déterminant le choix d'un système de pompage, l'éjecteur peut souvent se présenter comme une variante intéressante pour remplacer les systèmes centrifuges classiques. Les utilisations principales des éjecteurs dans le domaine du génie civil sont les suivantes :

\section{Dragage.}

On a dernièrement incorporé un éjecteur hydraulique à une drague hydraulique, avec des jets assurant la mise en suispension des matériaux de fond. Bien que le rendement de l'éjecteur ne soit pas élevé (coefficient (II) tableau I) par rapport à celui d'un groupe direct à capacité élevée, l'éjecteur présente cependant les avantages suivants :

a) Aucune eau chargée ne passe par la pompe;

b) Le tuyau d'aspiration des installations classiques fonctionne, cette fois, sous pression.

La figure 5 a montre le schéma d'une telle installation.

\footnotetext{
* $k$ étant la dimension de la rugosité.
} 


\section{Pompage à grande hauteur d'aspiration.}

On utilise couramment les éjecteurs avec des pompes centrifuges dans le domaine domestique [6], puisque, dans ce cas, le rendement offre moins d'importance que l'avantage découlant de la possibilité d'installer le groupe centrifuge au-dessus du niveau du sol (voir figure $5 b$ ). Dans ces installations, une partie du débit fourni par le groupe centrifuge sert à augmenter la pression d'aspiration, afin d'éviter les phénomènes de cavitation.

\section{Installation de pompage des puits.}

En utilisant une alimentation à haute pression, on peut faire débiter un nombre de puits de soutirage de la nappe (comportant des éjecteur's) contre des pressions appréciables [7] (voir figure $5 c$ ). Les avantages d'un tel système, par rapport aux installation classiques, sont les suivants :

a) Toutes les tuyauteries fonctionnent sous pression, facilitant ainsi la détection des fuites;

b) La hauteur aspirée par un seui étage peut largement dépasser la hauteur aspirée d'une installation classique ( 20 picds $)(6 \mathrm{~m})$;

c) Si de l'air est aspiré dans le puits, par exemple à la suite d'une baisse imprévue du niveau de la nappe, il sera évacué sans que le système ne se désamorce.

\section{Réduction des pressions dans les canaux de fuite.}

La possibilité d'utiliser des éjecteurs. en période de crue, afin de réduire les pressions dans les canaux de fuite, a été examinée en détail par ailleurs [8], tant pour les turbines Pelton que pour les turbines Francis et Kaplan. La figure $5 d$ montre le schéma d'une installation-type de ce genre.

\section{Dispositifs d'amorçage.}

Les ćjecteurs hydrauliques peuvent être utilisés pour provoquer l'amorçage rapide des siphons, à condition toutefois de disposer d'eau sous pression (fig. $5 e$ ). En fonctionnement continu, un tel éjecteur peut également éliminer les accumulations de vapeur provoquées par des phénomènes d'aération, ou par des fuites d'air lors du fonctionnement sous une charge négative.

La figure $5 f$ montre un dispositif simple assurant l'amorcage automatique d'une pompe centrifuge. Il comporte un petit réservoir branché sur l'aspiration de la pompe, et relié au côté aval de la vanne de refoulement par l'intermédiaire d'un éjecteur hydraulique. On ferme la vanne de refoulement au démarrage, et on alimente, à partir du réservoir, l'éjecteur évacuant l'air de la tuyauterie d'aspiration. Lorsque la totalité du conduit d'aspiration est remplie de liquide, on peut ouvrir la vanne de refoulement. Dans une telle installation, la perte de charge complémentaire due au réservoir est compensée par l'ahsence d'un clapet de pied.

\section{Pompage d'appoint.}

La figure $5 g$ montre le schéma d'un éjecteur hydraulique d'appoint, dans une conduite d'alimentation en charge. Les avantages de ce dispositif, par rapport aux pompes à basse pression et à débit élevé des installations classiques, sont les suivants :

a) Possibilité d'utiliser une pompe à vitesse spécifiçue moins élevée; celle-ci pourrait être d'un modèle couramment disponible dans le commerce;

b) Echange plus facile de la pompe, au cas où l'on désirerait, soit augmenter les pressions, soit monter une deuxième pompe en série;

c) Elimination des difficultés ressortant de la courbe de puissance ascendaute du groupe à puissance spécifique élevée;

d) Elimination des instabilités résultant de l'allure «aplatie» de la courbe caractéristique d'un tel groupe;

e) Pour une conduite souterraine profonde, la pompe motrice peut être installée au-dessus du niveau du sol, sans entraîner de pertes de pression appréciables;

f) L'étranglement et la tuyère peuvent être incorporés définitivement dans la conduite dès le début, étant donné qu'ils ne provoqueront qu'une faible résistance lorsqu'ils ne fonctionneront pas en pompage d'appoint;

g) Dimensions réduites des vannes de réglage;

h) Risque diminué de coups de bélier, lors du démarrage et de l'arrêt de l'installation.

L'examen de la figure 3 montre que le rendement, à la section de la tuyère d'un éjecteur d'appoint, peut être de l'ordre de $50 \%$. Les avantages économiques d'un tel système se voient le mieux au moyen d'un exemple :

\section{Exemple :}

On désire, dans une conduite, augmenter de 30 pieds, $(9,14 \mathrm{~m})$, la hauteur correspondant à un débit de 7 pieds-cubes/seconde (198 l/s). 
Quelles seraient les vitesses spécifiques des pompes nécessaires, avec et sans l'aide d'un ćjecteur hydraulique? Quelles seraient les dimensions des moteurs? La vitesse de rotation admise sera de $1650 \mathrm{tr} / \mathrm{mn}$ dans le deux cas.

Pour une pompe unique, la vitesse spécifique est de $\mathbf{n}_{\mathrm{s}}=7080$ (Unités : gallons (U.S.)/minute, pieds). Sur la base du rendement de 0,81 indiqué par Stepanoff [6], page 85 , la puissance du moteur devra être de 30 H.P.
Un éjecteur hydraulique, dont le coefficient d'étranglement est de 0,33 (voir fig. 3), fournit certaines valeurs de $\left(Q_{s}+Q_{m}\right) / Q_{m}$, (c'est-à-dire $\mathrm{M}+1)$, pour des valeurs déterminces de $\left(\mathbf{H}_{d}-\mathbf{H}_{s}\right) /\left(\mathbf{H}_{m}-\mathbf{H}_{s}\right)$, (c'est-à-dire $\left.\mathbf{N}^{\prime}\right)$.

On obtient ainsi la hauteur $\left(\mathrm{H}_{m}-\mathrm{H}_{s}\right)$, et le débit $\left(Q_{m}\right)$, de la pompe, et de là, $n_{s}$. En ulilisant les rendements indiqués par Stepanoff, comme ci-dessus, on peut alors determiner la puissance du moleur.

Ces valeurs sont résumées dans le tableau IV.

TABLEAU IV

Valeurs calculées pour l'étude d'une installation d'appoint à éjecteur hydraulique.

\begin{tabular}{|c|c|c|c|c|c|c|}
\hline $\mathrm{N}^{\prime}$ & $M+1$ & $\mathrm{H}_{m}-\mathrm{H}_{s}$ & $\mathrm{Q}_{m}$ & $n_{\mathrm{s}}$ & $\underset{\%}{\text { Rendement }}$ & $\begin{array}{c}\text { Puissance } \\
\text { H.P. }\end{array}$ \\
\hline 0,16 & 2,2 & 188 & 3,2 & 1220 & 83,0 & 82 \\
\hline 0,22 & 2,0 & 137 & 3,5 & 1610 & 85,5 & 6.4 \\
\hline 0,275 & 1,8 & 109 & 3,9 & 2030 & 86,5 & 56 \\
\hline 0,33 & 1,6 & 91 & 4,4 & 2480 & 87,0 & 52 \\
\hline 0,39 & 1,4 & 77 & 5,0 & 3000 & 86,0 & 51 \\
\hline 0,45 & 1,2 & 67 & 5,8 & 3600 & 85,5 & 52 \\
\hline
\end{tabular}

On voil que la solution «éjecteur» demande un moteur plus important, dont le coût supplémentaire doit cependant être compensé par les économies réalisées sur le prix de la pompe, des vannes, des groupes de secours, ainsi que par les divers avantages énumérés dans ce qui précède. On pourrait s'attendre à une légère amélioration des rendements indiqués par la figure 3, en utilisant un éjecteur de plus grande taille, c'est-à-dire que les courbes « $M-N$ 》 pourraient être déplacées vers la droite.

Une telle installation d'appoint pourrait trouver des emplois utiles dans les bassins de radoub, là où toute variation de la hauteur à laquelle est soumise la pompe, se trouve évitée. La hauteur de pompage disponible peut également être utilisée pour d'autres services, surtout s'il est possible de la répartír parmi des groupes pouvant être montés en série, ou en parallèle. La figure $5 h$ présente le schéma-type d'une telle installation.

Par ailleurs, dans les stations de pompage des installations d'épuration des eaux usées, on pourrait envisager la possibilité d'éliminer les matériaux solides d'une partie des effluents, el ensuite de faire passer cette partie par une pompe centrifuge classique, celle-ci entraînant un éjecleur hydraulique de dimensions pou- vant s'accommoder des matériaux solides. Le rendement global d'un tel système pourrail dépasser celui des pompes à boue classiques à large ouverture.

L'éjecteur hydraulique pourra certainement être utilisé pour résoudre des problèmes de drainage provisoire comportant de faibles hauteurs et de gros débits, d'autant plus que les groupes de pompagie mobiles disponibles pour les travaux de construction sont tous des modeles à hauteur relativement élevée, dans le cas considéré.

\section{Pompage des matériaux en suspension.}

L'importance du pompage des matériaux en suspension s'accroît, à mesure que les prix des autres methodes de transport augmentent. L'avantage présenté par un systime d'appoint, comportant des éjecteurs hydrauliçues, est ivident dans ce cas, s'il permel d'empêcher aux matériaux érosifs de pénétrer dans la pompe centrifuge. La figure $5 k$ montre le schéma d'une telle installation, dans laquelle seules les particules les plus fines passent par la pompe, étant donné que la vilesse d'écoulement à l’intéricur 
du tuyau ascendant est inférieure à la vitesse de décantation des gros matériaux.

En outre, cette disposition présente les avantages suivants :

a) Elle permet d'installer la pompe à un endroit commode, par rapport à la conduite;

b) Il n'y a aucun risque de colmatage de la turbine de la pompe par les matériaux solides, en cas d'arrêt;

c) Tant que le plafond du troncon de conduite «en Venturi » est calé à une cote constante, ainsi que le montre la figure, aucune accumulation de matériaux n'obturera la conduite.

\section{VI. - CONCLUSIONS}

L'étude et les essais faisant l'objet du présent ménoire conduisent aux conclusions suivantes :

a) Les calculs de rendements des éjecteurs hydrauliques diffèrent selon les utilisations. Il est possible d'atteindre des valeurs de l'ordre de 50 à $60 \%$ pour certaines utilisations en génie civil;

b) Les caractéristiques de ces éjecteurs sont nettement définies par les abaques $« \mathrm{M}-\mathrm{N}$ » (lesquels comprennent également des courbes d'égal rendement), sauf s'il y a cavitation. Bien que des études complémentaires sur certains aspects de la disposition des éjecteurs hydrauliques s'imposent, les connaissances actuelles sont néanmoins suffisantes pour en permettre, dès maintenant, une utilisation plus poussée;

c) La résistance due au frottement est moins élevée dans les éjecteurs de grande taille que dans ceux de plus faibles dimensions géométriques, ce qui, en principe, doit également en augmenter le rendement;

d) On a déjà utilisé des éjecteurs hydrauliques pour résoudre un grand nombre de problèmes de pompage différents, manifestement grâce à leur stabilité, et à la facilité avec laquelle ils s'adaptent à divers usages. Cependant, il paraît possible d'étendre encore davantage cette gamme d'utilisation.

\section{REFERENCES}

[1] J. E. Gosurne et M. P. O'Brien. - The Water Jet Pump, University of California, Pnb, in Eng., Vol. 3, No. 3, 1934, p. 167.

[2] D. Citrinis. - Contribution à l'ètude des éjecteurs, ou trompes hydrauliques, La Houllle Blanche, Vol. $11, n^{\circ} 6$, déc. 1956 , p. 837 .

[3] A. E. Kroll. - The Design of Jet Pumps. Chemical Eng. Prog., Vol. 1, 1947, p. 21.

[4] A.G. Beales et R.M. Perry. - Jet Pump Characteristics. Bachelor of Eng. Thesis, University of W.A., 1953 (unpublished).
[5] Axon. - Hydraulic Dredger, The Engineer, Vol. 206, 1958, p. 818.

[6] A.J. Stepanoff. - Centrifugal and Axial Flow Pumps, John Wiley \& Sons, 1948, 1st ed.

[7] Axon. - Water Removed Water from Deep Cutand-Cover Tunnel. Eng. News. Rec., Oct. 1, 1959 p. 34 .

[8] R. Sinvester. - Waier Jet Pump-Its use in HydroElectric Schemes, Water Power, Vol, 12, 1960 , p. 176 . 